\title{
Do Party Primaries Punish Women? Revisiting the Trade-off between the Inclusion of Party Members and the Selection of Women as Party \\ Leaders
}

\author{
Javier Astudillo \& Andreu Paneque
}

Draft version: December 2020

\begin{abstract}
This paper examines the effect of party primaries on women's chances of winning a leadership contest in eight Western parliamentary countries since 1985. By doing so, we revisit an ongoing debate about a possible trade-off between the democratic values of 'inclusion' of party members and 'representation' of excluded groups that this type of selection method may involve. Using an original data set consisting of 608 candidates who participated in 168 leadership mixed gender contests at the national or regional level, we show that female candidates perform worse under party primaries. This finding holds even after controlling for the types of candidate competing. We therefore sustain the argument that this leadership selection mechanism, in its current format, involves a tradeoff between 'inclusion' and 'representation'.
\end{abstract}

\section{Keywords}

leadership selection, mixed-gender contest, party primaries, women candidates

\section{Introduction}

In this paper we revisit the controversy about the impact of the type of leadership selection method on the presence of female party leaders, and more generally about a possible 
trade-off between the democratic goals of "inclusion" and "representation" that "party primaries" may involve.

The plebiscitary democratization of party leadership selection - usually referred to in Anglo-Saxon countries as "one-member-one-vote" (OMOV) -is a growing phenomenon in many older and newer democracies as part of a broader process of opening the intraparty decision-making process to all party members and even sympathizers (Astudillo and Detterbeck, 2020; Cross and Pilet, 2015). As a result, this inclusive selection procedure has attracted much academic interest in recent years (Cross et al., 2016; Sandri et al., 2015).

While opinion polls show that citizens are generally in favour of party primaries (Young and Cross, 2002), scholars tend to maintain a more sceptical view (Cross et al., 2016). One of their most important alleged shortcomings is the possible existence of a trade-off between the democratic values of "inclusion" and "representation" (Rahat et al., 2008). Opening the selection processes to the direct participation of the party rank and file, thereby increasing the inclusiveness of the process, may make it more difficult for traditionally under-represented groups, such as women, to be selected, consequently harming the demographic representativeness of the process outcome. While this proposal was initially elaborated for the selection of legislative candidates, it has also been extended recently to the selection of party leaders (Wauters and Pilet, 2015).

Unlike most of the existing research that focuses on the legislative power (Pruysers et al., 2017), as the first contribution of this paper, we focus on the selection of women for party leadership in contributing to this debate. On the one hand, their presence as party leaders is highly consequential. Given that prime ministers are typically selected from those serving as party leaders, their selection has clear implications for the composition of executives. In addition, the presence of female party leaders, as role models, can foster 
the selection of women for other political offices (Pruysers et al., 2017). Not surprisingly, some scholars, including Wauters and Pilet (2015:76), have concluded that "the position of the party leader [is] even more important than the number of women MPs in parliament". On the other hand, some studies suggest that women have faced different and more severe difficulties when running for executive versus legislative offices (Escobar-Lemmon and Funk, 2018; Fox and Oxley, 2003).

The second main contribution of this paper is our research strategy. While comparative studies analysing the selection of party leadership usually focus on the final outcome, those who became party leaders, in this paper we examine a prior stage: those who competed for this party office. This study offers, therefore, a systematic and multivariate analysis of how female candidates fare in comparison to their male counterparts depending on the leadership selection method. As our last contribution, our results suggest that the primaries trade-off is not so much a "supply-side" problem, i.e. the type of female candidate running, as a "demand-side" one, namely the type of selectorate involved.

It is important to remember, however, that our research goal is to assess the impact of the type of selection method on female candidates' likelihood of winning an internal contest for party leadership, and therefore whether party primaries involve a trade-off between some important democratic values. We do not seek to explain the "supply" of female candidates, that is, why sometimes women run in the first place. We acknowledge, however, that in practice, "supply" and "demand" factors are closely connected. First, unless actors are myopic, their evaluation of their "real" chances of winning (and therefore of the value of running) may depend on the past experience of other members of their group. Second, the type of selection method may increase a gendered selfselection bias. Under a specific type of selection method, female candidates have a higher 
chance of winning a leadership contest because under that procedure only women with ex ante high chances of winning are able, or dare, to run. Finally, as we further develop later, the average likelihood of winning of candidates of each gender is not independent of each gender's tendency to run under different selection methods.

\section{The controversy: a more direct participation of party members at the cost of fewer women in decision-making positions?}

Since the use of party primaries has become more common outside the United States, their appraisal has been controversial in academia. While some have considered this selection method to be part of a more general shift toward a more participatory style of politics (Kittilson and Scarrow, 2003), others have seen it as an instrument of party leaders aimed at reducing the influence of the most ideologically radical party activists by increasing the impact of the less active and more moderate party members (Mair, 1997:149). There is, however, a certain consensus that intra-party democracy is a multidimensional concept (Von Dem Berge et al., 2013). As a result, promoting some democratic values may dampen others (Cross and Katz, 2013:3).

The literature on candidate selection has suggested, therefore, that the type of selection method may affect the presence of women in their outcome. In a well-known study, Rahat et al. (2008) posited a trade-off between the democratic principles of "inclusion", "competition" and "representation". Leaving aside competition, they contended that the more inclusive a selectorate is, the worse the presence of under-represented groups in the outcome. As a result, the different democratic values "are unlikely to be simultaneously maximized in a single institution" (Rahat et al., 2008:676). Since then, other scholars 
have analysed this dilemma for the selection of party leaders as well (Cross et al., 2016; Verge and Astudillo, 2018; Wauters and Pilet, 2015).

Several causal mechanisms have been suggested for accounting for this trade-off in the selection of party leaders, including:

1) Gender stereotypes as heuristic cues: We know that citizens usually pay just passing attention to political news, often lacking the ability to organize their limited amounts of political information (Lawless and Pearson, 2008). But, in order to choose among primary candidates, citizens cannot use the heuristics they use when assessing candidates in general elections. In the latter, they can use partisan cues to make their election. In party primaries, all aspirants to the party candidacy provide the same party cue, so voters have to rely on other cues, of which gender stereotyping is one of the most straightforward (Fox and Oxley, 2003), and women are less likely to be seen to possess the qualities required for leadership positions (O’Neill et al., 2019).

2) Coordination problems among selectors: In primaries, the decision is made by a group of decentralized, atomized and anonymous individuals where meaningful deliberation about improving the representation of some social groups is not possible. Therefore, in contrast to more exclusive selectorates, consensus building, including "horse trading" and package deals, is unlikely to emerge. This explanation seems to fit better for the low selection of women as legislative candidates unless quotas are introduced. After all, the post of party leader is usually a single one ${ }^{1}$. But, as Wauters and Pilet (2015) argue, package deals can also be relevant in leadership selection. The designation of other party and political positions (deputy leader, leader of the parliamentary group, government minister, and so on) can be combined with the selection 
of the party leader. Exclusive selectorates are regarded as more suitable to undertake such balanced agreements.

These are rather "demand-side" explanations: women run in leadership contests but they are not chosen by the selectors. These arguments sustain the notion, therefore, that the winning chances of female candidates vary across different types of selection methods because selectorates differ in their evaluation of candidates according to their gender. Implicitly these explanations assume, however, that different types of selectors basically choose among the same type of candidates. This assumption is risky. The type of selection method may also affect the gendered "quality" of candidates, that is, the likelihood of individuals running with different ex ante chances of winning. As a result, different types of selectorates may actually choose among different types of male or female candidates. In short, the type of selection method may also foster a gendered self-selection bias. There are also several potential "supply-side" causal mechanisms, including:

1) Primaries' misleading image of fairness: If primaries foment the wrong perception that they "neutralize the bias of party elites against women" (Wauters and Pilet, 2015: 79), this wrong perception could encourage women with low chances of winning to run nonetheless. Accordingly, we would obtain a higher percentage of defeated female leadership candidates under this selection method. However, this difference would be simply the result of the same type of female candidates, those with low chances of winning, not daring to run in more exclusive selection methods in the first place. A higher rate of female defeats under primaries may not be caused, therefore, by a higher degree of bias against women or less political correctness among party members, but by an unfounded belief among potential aspirants that primaries make it easier to change the status quo against women ${ }^{2}$. 
2) Unequal media coverage: In primaries, the selectors, the party members and sympathizers are usually driven by media coverage, which may tend to focus more on men's campaigns (Baitinger, 2015). Name recognition as an asset in party primaries assumes that candidates are not unknown to the public. Women may have a more difficult time than men building name recognition because they tend to be less well known in political circles (Lawless and Pearson, 2008). Both factors can damage women's chances of winning the contest.

In brief, either because of problems of gender stereotyping and coordination among party members or because of female candidates' ex ante lower chances of winning, party primaries would be associated with a higher rate of female candidates' defeats.

\section{The current empirical evidence}

Empirical research on this topic is still scarce. Studies on the selection of women as party leaders have usually devoted little attention to the type of selection method (Bashevkin, 2010; O'Brien, 2015; O'Neill and Stewart, 2009). In addition, many of them focus on single countries. The few existing comparative analyses tend to reject, however, the importance of the type of selection method for the selection of women as party leaders (Cross et al., 2016; Verge and Astudillo, 2019; Wauters and Pilet, 2015).

Current studies tend to share several limitations. First, given the difficulty in getting data on the candidates running, these studies have focused instead on end-stage assessments of the leadership selection process: the selected party leaders. As a result, they cannot assess the impact of gender and type of selection method on candidates' chances of winning the process. Perhaps under a certain type of selection method there are fewer female leaders as outcome because fewer women run under that method in the 
first place. As argued by Lawless and Pearson (2008), for studying the factors promoting candidates with certain traits we need a pool of all those who ran, those who won and those who lost.

Second, the previous arguments about why party primaries are detrimental for women implicitly imply that women compete with men, but in the end, selectors - for whatever reason - prefer the male aspirant. This assumption implies two conditions absent in many leadership selection events (defined as a concrete internal process by which a party selects its leaders): first, that there is actual competition among several candidates in the process, something infrequent in many countries (Kenig et al., 2015: 59); and second, that there is at least one female contender (mixed-gender competition). Again this is not that common as we show later using our "wide dataset". We believe, therefore, that when analysing the impact of "party primaries" on female and male candidates' chances of becoming party leaders, only those selection events in which there is actual mixed-gender competition should be studied, rather than pooling together very different situations (no competition, single-sex competitions and mixed-gender competitions).

However, our strategy may have its own pitfalls. As argued previously, the first one is that the pool of candidates competing in mixed-gender contests is not a random sample of all candidates. Male and female candidates are not randomly assigned to have or not competitors, or to participate in primaries or other selection methods. Therefore, selfselection issues must be taken into account. As previously argued, the most important one is that we may have different "types" of male and female candidates across different types of selection methods.

But even though we could hold constant across types of selection method candidates' ex ante likelihood of winning, there is an additional confounding factor. The increase of 
the male over-representation among the candidates running under a specific type of selection contest - primaries, for example - may have the paradoxical effect of reducing the gap in the average likelihood of winning between male and female candidates.

The following example clarifies our point. Imagine that in a country there were 10 contests with a highly exclusive selectorate. Seven of these contests were won by a man, the rest by a woman. In addition, in each of these contests there was a strict gender balance of candidates: just one man competing against one woman. The probability of winning for male candidates was therefore $70 \%$, and $30 \%$ for female candidates. Imagine now that, for whatever reason, party primaries foster a male over-representation among candidates. Now in each primary contest there are two men running against a single woman. But the final outcome does not change. We have, as before, 10 mixed-gender contests, seven of them won again by men and three by women. As we can see, in both types of selection methods the gender bias in the final outcome is the same: $70 \%$ of the contests, no matter the type of selector, are won by men. But notice that now, under primaries, the average probability of winning for a male candidate is $35 \%$, much closer to the $30 \%$ for a female candidate. In short, the increase in the gender bias among the candidates has reduced the margin in the likelihood of winning of male over female candidates. The over-representation of male candidates is a factor to be controlled for.

With all these caveats in mind, we test the following hypothesis:

H: Ceteris paribus, female leadership candidates are less likely than men to win the selection process under party primaries than under other more exclusive selection methods.

\section{Data}


In order to confront the empirical challenges previously mentioned we have built two datasets: a wide dataset of all candidates in leadership selection events and a short dataset of those candidates running in mixed-gender contests. They were built by the authors using information obtained from internal party publications and websites, from newspapers, and published studies on parties and elections.

Wide dataset: This dataset contains all candidates, whether they were running for the first time or not, who formally have run for a "party leadership position" in the main parties of the centre left and centre right from the beginning of January 1985 to the end of December 2018 in eight parliamentary Western countries (see Table 1 in Appendix A for the list of parties studied in each country).

By "party leadership position" we are referring to the position of leading the party between elections as well as the position of being its "informal" candidate for the chief executive office in parliamentary countries (usually referred as "top candidates" Spitzenkandidat in German). In some countries (typically the Anglo-Saxon countries), parties have established a single process of leadership selection: once you are party leader, unless removed, you are the party's candidate for the post of prime minister. In others (such as Germany or Spain), party rules specify an additional procedure for selecting the candidate for a chief executive office (Astudillo and Detterbeck, 2020). Certainly, often the leader of the party between elections is merely "confirmed" as its top candidate. But this is not always the case (Samuels and Shugart, 2010). In these situations, we have studied therefore the selection of both the "party leader" (between elections) and the "top candidate" (during the parliamentary elections).

In order to increase the number of observations we have studied the selection events that took place at the national (federal) and regional (state) levels, as done by other 
scholars (Cross et al., 2016; Pruysers and Stewart, 2018). We know that additional data allow for increased precision of estimates.

Although there is now much information about those candidates running in national and regional party primaries in many countries, unfortunately this is not the case for other more exclusive and traditional selection methods. This precludes comparisons of selection method effects. Still, we have been able to find the necessary information about the selection of parties' leadership position for the following parliamentary countries: Australia, Austria, Belgium, Canada, Germany, Portugal ${ }^{3}$, Spain and the United Kingdom. We are therefore studying the regional and national levels in the same countries.

In this paper we follow a rather standard definition of "party primaries". For us, they are "the internal elections for selecting political leaders or candidates for office (either for parliamentary elections or for chief executive mandates, at all levels) that entail full membership votes (closed primaries), or votes by members, sympathisers and registered voters (open primaries)" (Sandri et al., 2015: 11). The type of party primaries we study are party regulated and for the most part "closed". Given the low number of cases of some more exclusive selection methods, especially when focusing on mixed-gender contests, unless otherwise stated we have classified them in a dichotomous way: whether a party selects its leaders through a vote by its members ("party primaries") or a different procedure ("non-primaries").

One of the empirical difficulties in classifying a selection event as a "party primary" is caused by those instances in which authority is shared between party members or even voters and more exclusive selectorates (such as conference delegates, legislators, etc.) (Cross et al., 2016). Sometimes this is the case because the selection decision is weighted 
by the size of different types of selectorates, as in the so-called "electoral colleges". Sometimes, one selectorate chooses among candidates previously filtered by another selectorate (as is currently the case in the Spanish and British Conservative parties). We have, therefore, studied which candidacy won in each respective selectorate.

In all our countries, apart from Canada and Belgium, we have studied, at the national level, the two most important parties. These tend to be one party from the centre left (such as the Australian Labor Party) and one party from the centre right (such as the Australian Liberal party $)^{4}$. At the regional level we have studied their party branches, as well as the main "regional parties" (see Table 1 in Appendix A). We have selected these parties for theoretical and practical reasons. First, these are the parties that most national and regional chief executives belong to. Secondly, and this is not a minor issue, the media report much more extensively the selection events of big parties (who is entitled to vote, the candidates, the share of the winner, etc.) than they do for "minor" or "fringe" parties.

Certainly, the relationship between the "national parties" and their "branches" varies across countries. Canada and Belgium are probably the most peculiar cases. In Canada, the federal New Democratic Party (NDP) has wings in almost all provinces, the Liberals in just four, whereas the remaining provincial Liberal parties operate as separate entities, and the Conservative Party of Canada (CPC) has no formally provincial wings. Nevertheless, these separate provincial Liberal and Conservative parties are distinct from ethno-regional parties, such as the Parti Quebecois, and are ideologically linked with the federal parties. In Belgium the main parties are not nationwide. Most of them are the product of the split of previous national parties in their Walloon and Flemish branches ${ }^{5}$.

This "wide dataset" is composed of 3,600 candidates (notice that some individuals have run several times) taking part in 2,602 selection events ${ }^{6}$. 
Short dataset: As previously explained, from this dataset we have subtracted a sample of those candidates who run in mixed-gender contests. This drastically reduces our dataset to 608 candidates, of which 211 (34.7\%) were female and 397 (65.3\%) male. Finally, 455 candidates $(74.8 \%)$ have run at the regional level and 153 at the national level ${ }^{7}$. This is the dataset we use to gauge the effect of the type of selector on the likelihood that a woman wins a selection contest.

Descriptive analysis: types of selection method and socio-demographic and political background of leadership candidates

Before assessing the gendered effect of party primaries, we review the main gender traits of all the analysed selection events and the mixed-gender contests. Tables 1 to 4 use the wide dataset, and the units of analysis are the "leadership selection events", while the rest of tables uses the short dataset and the units are the individual "candidates" running in mixed-gender contests.

Table 1 shows that among our eight countries party congresses are still the most frequent type of selection method both at the national and regional levels ${ }^{8}$. Our figures are not very different from those offered by Lisi et al. (2015: 20), although they studied more countries and a bigger range of parties.

\section{TABLE 1 HERE}


Table 2 also shows that, as has already been noted (Kenig et al., 2015: 71), among the most widely employed selection methods party primaries are characterized by a higher tendency to have more than one single candidate seeking the leadership of the party. While only $13.7 \%$ of leaders are selected, or reselected, in a contested party congress, in the case of party primaries the percentage goes up to $53.5^{9}$. Less frequently mentioned is the fact that party primaries also seem to encourage mixed-gender contests. This also explains the higher absolute number of candidates competing under party primaries (388 candidates) than under all the other selection methods (220 candidates) in our short dataset.

TABLE 2 HERE

There are, however, two circumstances that must be taken into account when analysing the gendered effect of selection methods. First, across time, women are increasingly aspiring to the party leadership in both absolute and relative numbers, both at the national and regional levels. This is reflected in the increasing proportion of selection events that are mixed gendered (see Table 3).

\section{TABLE 3 HERE}

Secondly, across countries, Table 4 shows that the Anglo-Saxon countries (Australia, Canada and the United Kingdom) not only have more contested selection events than the 
other countries as already shown (Kenig et al., 2015:60) but also a much higher percentage of mixed-gender contests.

\section{TABLE 4 HERE}

Focusing now on those selection events where men and women compete to become party leader, as explained before, we have classified the different contests as either "party primary" or "non-primary". Table 5 indicates that while female candidates perform better than their male competitors in "non-primary" contests, they perform worse than their male counterparts in "party primaries" 10 . This is, therefore, the first sign suggesting that selection by party primaries could be detrimental for female candidates' chances of becoming party leaders.

\section{TABLE 5 HERE}

But, as already said, the "type" of male and female candidate may vary across selection methods. The following table shows some of the socio-demographic and political traits of our candidates competing in mixed-gender contests, such as: age, first time running as candidate, "outsiderism" (no previous public office experience or just at local level), and party leadership (for those party leaders seeking reselection, or nomination as top candidate when separate selection processes exist).

TABLE 6 HERE 
Table 6 shows that age makes no difference, and that under primaries there is a slight increase in the presence of new candidates, but primaries seem to foster "outsiderism" in the specific case of men (no effect among women). However, party leaders seeking reselection seem to be more frequent in the absence of primaries for the specific case of women. These data mean that we have to control for the "type" of candidate running under different selection methods, although it is not clear a priori what the direction of bias is.

\section{Multivariate analysis: are party primaries really a stumbling block for women?}

We have run four regression models. In all of them our dependent variable is a dummy variable where " 0 " means the candidate lost and " 1 " that they won the mixed-gender contest. Our main independent variables are the gender (female) of the candidates (where " 0 " is a male aspirant and " 1 " is female) and the type of selectorate (primaries) where " 0 " identifies exclusive selectorates and " 1 " a vote among party members. We have thus created an interaction term between these two variables (female*primaries).

As is well known, however, the type of selectorate is not the only determinant for the gender representativeness of party leaders. Following the work by Stambough and O'Regan (2007), we have classified other factors affecting women's chances of becoming party leader in two clusters. The first cluster is referred to as the "pipeline model", and the second one as the "sacrificial lamb".

The first theoretical model refers to the fact that winning a competition involves having the qualifications and personal features desired by those who vote in an election, as well as having the resources to fight for it (such as political contacts, economic resources and media access). Several factors can thus favour the selection of women. 
Party ideology (right party): Parties with a high commitment towards gender equality will be more likely to have women at the highest ranking level of the party as a compensation for previous male dominance. Leftist parties are generally more open to disadvantaged groups in society (including women) and therefore also tend to have better representation of these groups (Kittilson, 2006). Running in these parties is expected to increase the likelihood of winning. In our study, however, we have only a limited ideological variation since we only study mainstream parties (one from the left and one from the right). The variable is a dummy coded " 0 " for a centre-left party and 1 for a centre-right party.

Proportion of women in parliament (\% female legislators): Studies on national cabinets have noted that the share of female parliamentarians affects the supply of eligible women ministers and gives a clue to the general openness of a political system to women's participation (Jalalzai, 2008: 213). This also applies to regional politics. For example, in the United States, female gubernatorial candidates are more commonly found in states with a larger share of women MPs (Stambough and O'Regan, 2007: 363).

Number of previous female party leaders (num. past female leaders):Breaking the "glass ceiling" within parties for a first time might reshape party members' attitudes toward future selection of women as party leaders. We have thus studied the number of previous female party leaders in each party before a given contest.

The second theoretical model, the "sacrificial lamb", refers to the dominant culture in society in which women take up subordinate roles, while it is seen as normal that men hold powerful positions. This implies that women are more likely to take prominent positions when the stakes are low; in other words, women are more likely to win nominations when men have a low desire for them, such as being the party leader for a 
party with low expectations of winning the next election. As proxies of a less desirable party's leading position we use the following variables:

Party size (party size): The size of the party in previous elections is related to their probability of winning the next election. So if women are selected as party leaders when parties have less chance of winning the next election, they will be selected in higher proportions in smaller parties. We look here at each party's electoral share in the immediate election before the mixed-gender contest.

Exit from government (lost government): Having been expelled recently from power involves parties having to undertake a costly "crossing of the desert" to recover the support of the public. Therefore, the expectations of being in government again are low. Ambitious male politicians may therefore wait for the public opinion of the ruling parties to deteriorate. In addition, defeated parties may select women as a signal of renovation and breaking with old practices. This variable is codified as " 1 " if the party lost the election recently and " 0 " otherwise.

Territorial level (national level): In general, regional positions are traditionally considered political positions with a lower degree of power and prestige than holding positions at the national level (Astudillo and Martínez-Cantó, 2020). This may reduce the desirability of such offices for ambitious male politicians, leaving them available to women. Parties may also feel that they risk less politically when "experimenting" with the selection of women as party leaders and top candidates at the regional level. In fact, selecting women at this level can be a "compensatory strategy" for not selecting them to lead the national parties. This variable is codified as " 0 " for the regional level and " 1 " for the national level. 
Finally, given the particularities of Anglo-Saxon countries related to the presence of women in a contest, we have also controlled for this variable.

As previously stated, in the second regression model we control for the possible confounding effect of the over-representation of male candidates on the comparison of males' and females' likelihood of winning ${ }^{11}$. We have therefore included the absolute number of male candidates each female candidate competed with (num. male contenders).

In the third regression model we also control for "type" of candidate running, specifically: age of the candidate (candidate age), whether the candidate was a political outsider or a 'local' politician (outsider-local), that is, the candidate had held no public office, or had been a town councillor, or mayor of a town of less than 10,000 inhabitants ${ }^{12}$, first time running in a contest (first time running), and finally if they were a party leader seeking reselection or top candidacy nomination (incumbent party leader) ${ }^{13}$.

All models include territory (country for the national candidates, region for the regional candidates) and decade fixed effects, and robust standard errors clustered by party. Given the dichotomous nature of the dependent variable, we have used logistic regression models.

According to the results of the first model (see Table 7), we can see that the effect of gender on candidates' chances of winning depends on the type of selection method. Note that this effect increases its statistical significance, bordering now on $99 \%$ significance, when controlling for the number of male candidates running in each contest (model 2). We have wondered, however, if the fact that female candidates perform worse under party primaries is because this selection system fosters the presence of "weak" female candidates, those with a priori a lower chance of winning -given their age, novelty, and lack of party and political experience. In model 3 we can see, however, that after 
controlling for these factors, the effect of gender on candidates' chances of winning a mixed-gender contest still depends on the selection method. To make this effect more explicit, we have calculated the predicted probabilities (see Graph 1). While under nonprimaries male and female candidates have roughly the same likelihood of winning a leadership contest, women tend to perform significantly worse than men under party primaries. On average, female candidates are 14 percentage points less likely to win the party primaries than their male counterparts. Actually, for men, the type of selection method does not affect their chance of winning. For women it does significantly.

\section{TABLE 7 HERE}

\section{GRAPH 1 HERE}

The fact that party primaries are detrimental for women after controlling for the personal qualities of candidates seems to suggest that there is a real problem of "demand". If female candidates perform worse under primaries, it is not because women running in primaries are "weaker contenders" than women running in non-primary selection contests, but because primary selectors tend to prefer men, even though there is no difference in the "quality" of male and female candidates. As regards our control variables, we can see in model 3 that in general candidates running for the first time, who are younger and have political experience tend to perform better. Equally, as the number of male candidates increases, the chances of candidates winning decrease. Finally, candidates in smaller parties perform better than in bigger parties. Subsequent analysis could assess whether these general effects also depend on candidates' gender. 
Finally, in order to be more confident about our findings, we have performed two additional robustness checks. First, given that in our models we have pooled together national and regional candidates, we have rerun model 3 but focusing only on the regional level. We lose therefore 132 national candidates. The results in model 4 of Table 7 , however, are basically the same. The effect of gender on the chances of candidates winning a regional mixed-gender contest depends on the type of selection method. Second, we have rerun model 3 but this time we have classified the type of selection method as party primaries, party congresses and others. The results, given in Appendix $\mathrm{B}$, show that again female candidates perform significantly worse in primaries than in congresses (there is no statistically significant difference with other more exclusive method, but this category has much fewer cases than the other two).

\section{Conclusions}

This paper has examined the effect of party primaries on women's chances of winning a leadership contest in eight Western parliamentary countries since 1985. We thus revisited the debate about a possible trade-off between the goals of "inclusion" and "representation". We have used a new dataset consisting of every woman and men who entered a mixed-gender leadership contest of the main political parties of the left and right either at the national or regional level. We acknowledge, nonetheless, that the reasons for the very low number of female party leaders are much broader than just a problem with the selection method employed. The issue is whether this is an additional stumbling block for women.

Our most important finding is that, contrary to the current view that the leadership selection method is gender-neutral, female candidates perform worse than their male 
counterparts under party primaries than under more exclusive selection methods. Rahat et al.'s (2008) original argument highlighting the unwanted consequences of primaries for the selection of legislative candidates is therefore sustained for the selection of party leaders. No matter how popular party primaries are among the public, they seem to add an extra stumbling block for the selection of women. More people participating in the selection of party leaders may be at the cost of more representative outcomes.

We have also reviewed the "supply-side" argument of selection bias being the result of primaries fostering female candidacies with low chances of winning while the same type of woman would not bother to run under more exclusive selection methods. This may be the result of party primaries offering a misleading image of "renovation". After controlling for the type of candidate, however, party primaries are still detrimental for female candidates' chances of winning a mixed-gender contest. We therefore suggest that we are actually facing a "demand-side" problem. Different types of selectors seem to matter. But further studies at the individual level on party selectors are needed to fully reveal the causal mechanisms that make primaries detrimental for female candidates.

Our results could lead to a proposal of getting rid of primaries, as Rahat et al. (2008) seem to suggest, under the argument that all democratic values do not have to be maximized within all social institutions but across a combination of them. We can also explore, however, other mechanisms to make compatible the democratic values of inclusion and representation within the same institution. Perhaps another possibility is the implementation of dual mixed-gender party leaderships as some parties are starting to do. As a result, party members are not forced to choose between male and female candidates. Both women and men are selected. This kind of "quota" system for party leadership would also solve supply-side problems regarding having women as party leaders since 
women's presence is guaranteed. The issue of who would become the party's top candidate remains, however, unresolved. 


\section{References}

Astudillo, J., \& Martínez-Cantó, J. (2020). Political professionalization, subnational style: Political insiders and the selection of candidates for regional premiership in Spain. Regional \& Federal Studies, 30(4), 557-578.

Astudillo, J., \& Detterbeck, K. (2020). Why, sometimes, primaries? Intraparty democratization as a default selection mechanism in German and Spanish mainstream parties. Party Politics, 26(5), 594-604.

Bashevkin, S. (2010). When do outsiders break in? Institutional circumstances of party leadership victories by women in Canada. Commonwealth and Comparative Politics, 48(1), 72-90.

Baitinger, G. (2015). Meet the Press or Meet the Men? Examining Women's Presence in American News Media. Political Research Quarterly, 68(3), 579-592.

Cross, W. P., \& Katz, R. S. (2013). The Challenges of Intra-Party Democracy. https://doi.org/10.1093/acprof:oso/9780199661879.003.0001

Cross, W. P., \& Pilet, J.-B. (2015). The Politics of Party Leadership: a cross-national perspective. Oxford: Oxford University Press.

Cross, W. P., Kenig, O., Pruysers, S., \& Rahat, G. (2016). The Promise and Challenge of party primary elections: a comparative perspective. Montreal: McGill-Queen's University Press. 
Eagly, A. H., \& Karau, S. J. (2002). Role congruity theory of prejudice toward female leaders. Psychological Review, 109(3), 573-598.

Escobar-Lemmon, M., \& Funk, K. (2018). Women's Representation in Subnational Goverments. In L. Schwind-Bayer (Ed.), Gender and Representation in Latin America (pp. 99-118). Oxford: Oxford University Press.

Fox, R. L., \& Oxley, Z. M. (2003). Gender stereotyping in state executive elections: Candidate selection and success. Journal of Politics, 65(3), 833-850.

Jalalzai, F. (2008). Women Rule: Shattering the Executive Glass Ceiling. Politics and Gender, 4(2), 205-231.

Kenig, O., Rahat, G., \& Tuttnauer, O. (2015). Competitiveness of Party Leadership Selection Processes. In W. P. Cross \& J.-B. Pilet (Eds.), The Politics of Party Leadership: a cross-national perspective. Oxford University Press.

Kittilson, M. . (2006). Challenging parties, changing parliaments: Women and elected office in contemporary Western Europe. Columbus: Ohio State University Press.

Kittilson, M. ., \& Scarrow, S. (2003). Political Parties and the Rhetoric and Realities of Democratization. In B. E. Cain, R. J. Dalton, \& S. Scarrow (Eds.), Democracy Transformed? Expanding Political Opportunities in Advanced Industrial Democracies (pp. 59-80). Oxford: Oxford University Press. 
Lawless, J. L., \& Pearson, K. (2008). The primary reason for women's underrepresentation? Reevaluating the conventional wisdom. Journal of Politics, 70(1), $67-82$.

Mair, P. (1997). Party System Change: Approaches and interpretations. Oxford: Clarendon Press.

O’Brien, D. Z. (2015). Rising to the Top: Gender, Political Performance, and Party Leadership in Parliamentary Democracies. American Journal of Political Science, 59(4), $1022-1039$.

O’Neill, B., \& Stewart, D. K. (2009). Gender and political party leadership in Canada. Party Politics, 15(6), 737-757.

O’Neill, B., Pruysers, S., \& Stewart, D. K. (2019). Glass Cliffs or Partisan Pressure? Examining Gender and Party Leader Tenures and Exits. Political Studies. https://doi.org/10.1177/0032321719880316

Pruysers, S., Cross, W. P., Gauja, A., \& Rahat, G. (2017). Candidate Selection Rules and Democratic Outcomes: The impact of parties on women's representation. In S. Scarrow, P. Webb, \& T. Poguntke (Eds.), Organizing Political Parties: Representation, participation, and power (pp. 208-233). Oxford: Oxford University Press. 
Pruysers, S., \& Stewart, D. K. (2018). Federal-provincial variation in leadership selection: processes and participation. Journal of Canadian Studies, 52(3), 742-764.

Rahat, G., Hazan, R. Y., \& Katz, R. S. (2008). Democracy and political parties: On the uneasy relationships between participation, competition and representation. Party Politics, 14(6), 663-683.

Samuels, D. J., \& Shugart, M. S. (2010). Presidents, Parties, and Prime Ministers: how the separation of powers affects party organization and behavior. Cambridge: Cambridge University Press.

Sandri, G., Seddone, A., \& Venturino, F. (2015). Party Primaries in Comparative Perspective. Farnham: Ashagate Publishing Limited.

Stambough, S. J., \& O'regan, V. R. (2007). Republican Lambs and the Democratic Pipeline: Partisan Differences in the Nomination of Female Gubernatorial Candidates. Politics and Gender, 3(3), 349-368.

Young, L., \& Cross, W. (2002). The rise of plebiscitary democracy in Canadian political parties. Party Politics, 8(6), 673-699.

Verge, T., \& Astudillo, J. (2019). The gender politics of executive candidate selection and reselection. European Journal of Political Research, 58(2), 720-740. 
Von dem Berge, B., Poguntke, T., Obert, P., \& Tapei, D. (2013). Measuring Intra-Party Democracy: A guide for the content analysis of party statues. London: Springer.

Wauters, B., \& Pilet, J.-B. (2015). The selection of female party leaders. Does the selectorate make a difference? In W. Cross \& J.-B. Pilet (Eds.), The Politics of Party Leadership: a cross-national perspective. (pp. 73-89). Oxford: Oxford University Press. 
TABLES AND GRAPHS

Table 1. Relative and absolute use of different types of selection methods across territorial levels (selection of interim leaders excluded)

\begin{tabular}{|c|c|c|c|}
\hline & National level & Regional level & Total \\
\hline Primaries & $\begin{array}{c}27.1 \% \\
(81)\end{array}$ & $\begin{array}{c}12.8 \% \\
(276)\end{array}$ & $\begin{array}{c}14.6 \% \\
(357)\end{array}$ \\
\hline Congress & $\begin{array}{c}45.2 \% \\
(138)\end{array}$ & $\begin{array}{c}62.6 \% \\
(1,345)\end{array}$ & $\begin{array}{c}60.6 \% \\
(1,483)\end{array}$ \\
\hline Parliamentary group & $\begin{array}{c}10.4 \% \\
(31)\end{array}$ & $\begin{array}{l}5.8 \% \\
(125)\end{array}$ & $\begin{array}{l}6.4 \% \\
(156)\end{array}$ \\
\hline Party organ & $\begin{array}{c}13.0 \% \\
(39)\end{array}$ & $\begin{array}{c}17.6 \% \\
(378)\end{array}$ & $\begin{array}{c}17.0 \\
(417)\end{array}$ \\
\hline Mixed selectorate & $\begin{array}{c}3.0 \% \\
(9)\end{array}$ & $\begin{array}{c}0.6 \% \\
(12)\end{array}$ & $\begin{array}{c}0.9 \% \\
(21)\end{array}$ \\
\hline Other & $\begin{array}{c}0.3 \% \\
(1)\end{array}$ & $\begin{array}{c}0.7 \% \\
(14)\end{array}$ & $\begin{array}{c}0.6 \% \\
(15)\end{array}$ \\
\hline Total & $\begin{array}{c}100.0 \% \\
(299)\end{array}$ & $\begin{array}{l}100.0 \% \\
(2,150)\end{array}$ & $\begin{array}{l}100.0 \% \\
(2,449)\end{array}$ \\
\hline
\end{tabular}

"Mixed selectorate" refers to both "weighted systems", such as the "electoral college", and "multi-stage systems" (Cross et al., 2016:31)

Table 2. Percentage of selection events with several contenders, and mix-gendered, across types of selection method (absolute number of cases in parentheses)

\begin{tabular}{|l|c|c|}
\hline & Several contenders & Mixed-gender contest \\
\hline Primaries & 53.5 & 24.1 \\
& $(191)$ & $(86)$ \\
\hline Congress & 13.7 & 3.7 \\
& $(196)$ & $(52)$ \\
\hline Parliamentary group & 42.5 & 11.3 \\
& $(57)$ & $(15)$ \\
\hline Party organ & 1.0 & 0.0 \\
& $(4)$ & $(0)$ \\
\hline Mixed selectorate & 95.2 & 52.4 \\
& $(20)$ & $(11)$ \\
\hline Other & 46.7 & 26.7 \\
& $(7)$ & $(4)$ \\
\hline Total & 20.1 & 7.1 \\
& $(475)$ & $(168)$ \\
\hline
\end{tabular}

In both columns percentages are calculated over the total number of selection events. 
Table 3. Percentage of selection events that are mix-gendered across time and territorial levels (absolute number of cases in parentheses)

\begin{tabular}{|l|c|c|}
\hline Period & National level & Regional level \\
\hline 1985-1999 & 7.6 & 4.7 \\
& $(10)$ & $(37)$ \\
\hline $2000-2009$ & 9.4 & 5.5 \\
& $(9)$ & $(36)$ \\
\hline $2010-2018$ & 20.0 & 9.6 \\
& $(15)$ & $(61)$ \\
\hline Total & 11.2 & 6.5 \\
& $(34)$ & $(134)$ \\
\hline
\end{tabular}

In both columns percentages are calculated over the total number of selection events.

Table 4. Percentage of selection events with several contenders, and mix-gendered across type of country (absolute number of cases in parentheses)

\begin{tabular}{|l|c|c|}
\hline & Several contenders & Mixed-gender contest \\
\hline Anglo-Saxon & 63.7 & 28.4 \\
& $(223)$ & $(99)$ \\
\hline Non-Anglo-Saxon & 12.4 & 3.4 \\
& $(252)$ & $(69)$ \\
\hline Total & 19.9 & 7.0 \\
& $(475)$ & $(168)$ \\
\hline
\end{tabular}

In both columns percentages are calculated over the total number of selection events.

Table 5. Percentage of candidates winning mixed-gender contests across gender and type of selection method

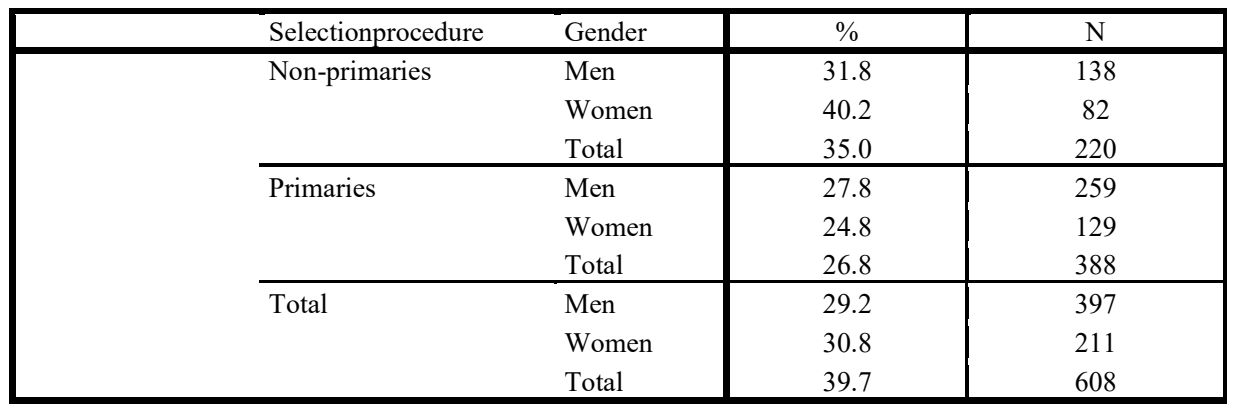


Table 6. Age and political traits of candidates running in mixed-gender contests across gender and type of selection method (absolute number of cases in parentheses)

\begin{tabular}{|r|c|c|c|c|}
\hline & Mean age & \% first time running & \% outsider-local & \% incumbent leaders \\
\hline Non-primary & & & & \\
Men & 48.9 & 80.9 & 14.9 & 7.2 \\
& $(130)$ & $(136)$ & $(134)$ & $(138)$ \\
Women & 48.2 & 82.7 & 19.5 & 15.9 \\
& $(77)$ & $(81)$ & $(82)$ & $(82)$ \\
\hline Primary & & & & 5.0 \\
Men & 48.9 & 85.8 & 21.5 & $(259)$ \\
& $(248)$ & $(254)$ & $(251)$ & 7.0 \\
Women & 48.1 & 86.7 & 18.6 & $(129)$ \\
& $(126)$ & $(128)$ & $(129)$ & \\
\hline
\end{tabular}

Some columns do not summed 608 cases because of lack of information in some candidates 
Table 7. The conditional effect of gender and type of selection method on the chances of candidates winning mixed-gender contests

\begin{tabular}{|c|c|c|c|c|}
\hline & Model 1 & Model 2 & Model 3 & Model 4 \\
\hline Female & $\begin{array}{l}.160 \\
(.258)\end{array}$ & $\begin{array}{l}.082 \\
(.260)\end{array}$ & $\begin{array}{l}.054 \\
(.365)\end{array}$ & $\begin{array}{l}.175 \\
(.361)\end{array}$ \\
\hline Primaries & $\begin{array}{l}.025 \\
(.121)\end{array}$ & $\begin{array}{l}.187 \\
(.120)\end{array}$ & $\begin{array}{l}.086 \\
(.212)\end{array}$ & $\begin{array}{c}.227 \\
(.278)\end{array}$ \\
\hline Female*Primaries & $\begin{array}{c}-.655^{* *} \\
(.281)\end{array}$ & $\begin{array}{c}-.771 * * \\
(.303)\end{array}$ & $\begin{array}{c}-.893 * * \\
(.384)\end{array}$ & $\begin{array}{c}-.997 * * \\
(.493)\end{array}$ \\
\hline First time running & - & - & $\begin{array}{c}.767 * * * \\
(.262)\end{array}$ & $\begin{array}{c}1.191^{* * *} \\
(.447)\end{array}$ \\
\hline Incumbent party leader & - & - & $\begin{array}{c}.977 \\
(.741)\end{array}$ & $\begin{array}{l}1.327 \\
(.967)\end{array}$ \\
\hline Candidate age & - & - & $\begin{array}{c}-.036^{* *} \\
(.016)\end{array}$ & $\begin{array}{l}-.034^{*} \\
(.019)\end{array}$ \\
\hline Outsider-local & - & - & $\begin{array}{c}-1.337 * * * \\
(.397)\end{array}$ & $\begin{array}{c}-1.281 * * * \\
(.402)\end{array}$ \\
\hline Num. male contenders & - & $\begin{array}{c}-.330 * * * \\
(.039)\end{array}$ & $\begin{array}{c}-.377 * * * \\
(.072)\end{array}$ & $\begin{array}{c}-.445 * * * \\
(.093)\end{array}$ \\
\hline Right party & $\begin{array}{l}.158 * * \\
(.079)\end{array}$ & $\begin{array}{c}.197 * * * \\
(.058)\end{array}$ & $\begin{array}{c}.079 \\
(.082)\end{array}$ & $\begin{array}{l}-.021 \\
(.119)\end{array}$ \\
\hline$\%$ female legislators & $\begin{array}{l}.008 \\
(.007)\end{array}$ & $\begin{array}{l}.005 \\
(.005)\end{array}$ & $\begin{array}{c}.005 \\
(.011)\end{array}$ & $\begin{array}{c}.004 \\
(.010)\end{array}$ \\
\hline Num. past female leaders & $\begin{array}{l}-.061 \\
(.079)\end{array}$ & $\begin{array}{l}-.017 \\
(.066)\end{array}$ & $\begin{array}{l}-.112 \\
(.095)\end{array}$ & $\begin{array}{l}-.154 \\
(.100)\end{array}$ \\
\hline Party size & $\begin{array}{c}-.016^{* * *} \\
(.005)\end{array}$ & $\begin{array}{l}-.001 \\
(.001)\end{array}$ & $\begin{array}{c}-.017 * * * \\
(.004)\end{array}$ & $\begin{array}{c}-.019 * * * \\
(.006)\end{array}$ \\
\hline Lost government & $\begin{array}{c}-.002 \\
(.199)\end{array}$ & $\begin{array}{c}.398 * * * \\
(.132)\end{array}$ & $\begin{array}{l}.066 \\
(.119)\end{array}$ & $\begin{array}{l}-.099 \\
(.171)\end{array}$ \\
\hline National level & $\begin{array}{c}-1.134 * * * \\
(.196)\end{array}$ & $\begin{array}{c}-.865 * * * \\
(.125)\end{array}$ & $\begin{array}{l}-.561 \\
(.595)\end{array}$ & - \\
\hline Anglo-Saxon country & $\begin{array}{c}.985 * * * \\
(.312)\end{array}$ & $\begin{array}{c}.588 * * * \\
(.219)\end{array}$ & $\begin{array}{c}.187 \\
(.307)\end{array}$ & $\begin{array}{l}-.767 \\
(.644)\end{array}$ \\
\hline Territory dummies & Yes & Yes & Yes & Yes \\
\hline Decade dummies & Yes & Yes & Yes & Yes \\
\hline Constant & $\begin{array}{l}.376 \\
(.415)\end{array}$ & $\begin{array}{c}.516^{* * * *} \\
(.198)\end{array}$ & $\begin{array}{c}2.635 * * \\
(1.106)\end{array}$ & $\begin{array}{c}2.161 \\
(1.335)\end{array}$ \\
\hline Pseudo $\mathrm{R}^{2}$ & .05 & .08 & .12 & .13 \\
\hline $\mathrm{N}$ & 569 & 569 & 527 & 395 \\
\hline
\end{tabular}

Robust standard errors in parentheses.

$* * * \mathrm{p}<0.01, * * \mathrm{p}<0.05, * \mathrm{p}<0.1$. 


\section{Graph 1.}

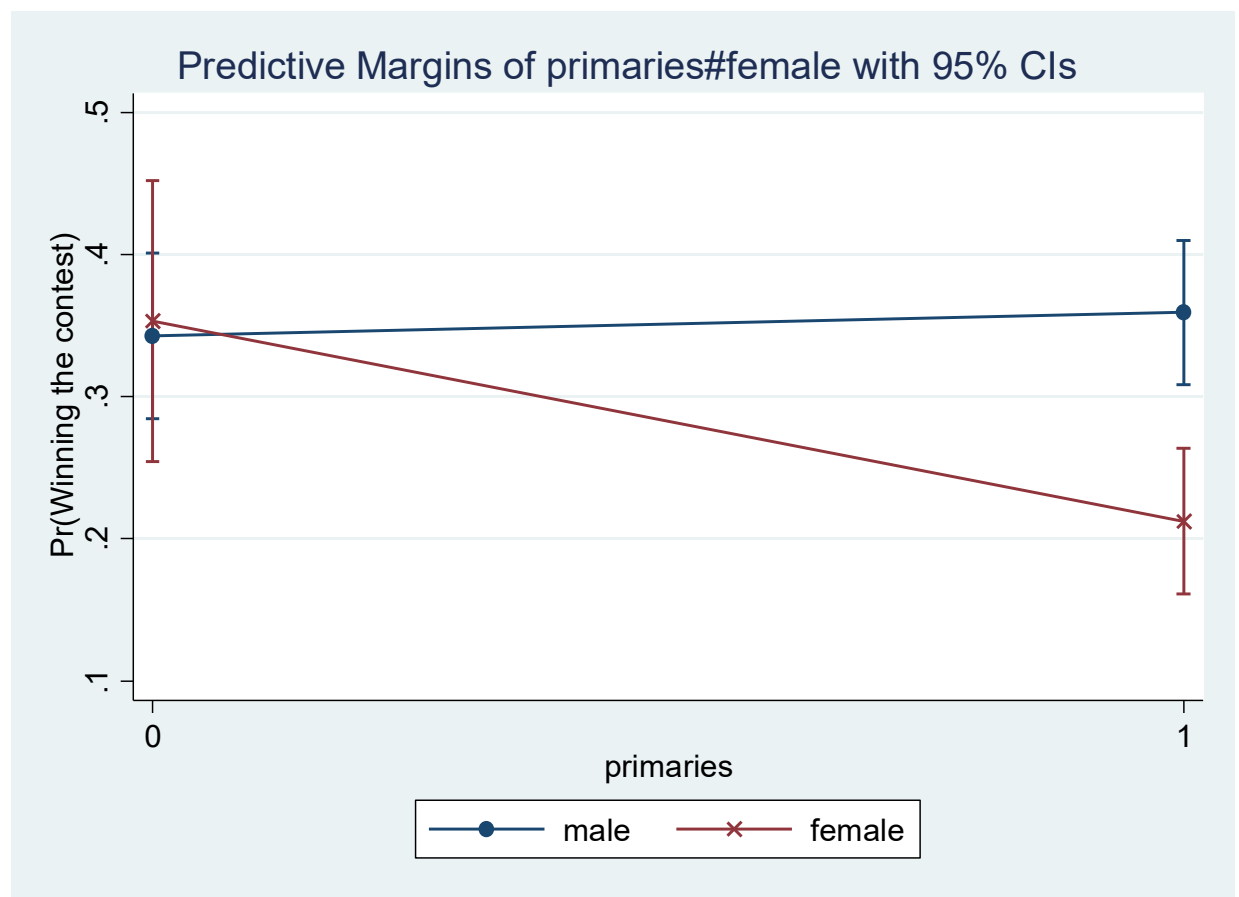

${ }^{1}$ Some parties, such as the German Greens, have a dual mixed-gender leadership.

${ }^{2}$ We cannot exclude the possibility, however, that party primaries could also foster the presence of "weak" candidates among men. After all, as politics has been traditionally a masculine sphere, it can be natural for men to run in contests for testimonial purposes.

${ }^{3}$ In Portugal we looked at the autonomous regions of Madeira and the Azores islands.

${ }^{4}$ In Canada we have also included the third party, the NDP, and in Belgium parties from the liberal, socialist and Christian democratic families.

${ }^{5}$ However, given that their leaders tend to be involved in national politics (for example becoming national prime ministers), we have classified their primaries as "national" (see Table 1 in Appendix A).

${ }^{6}$ We have excluded the selection of "interim leaders".

${ }^{7}$ In Appendix A, Table 2, we show the number of candidates by country and territorial level.

${ }^{8}$ Table 1 only shows 2,449 cases because of lack of information about the actual selection method employed in some selection events. In a few of them we were also unable to find the number of contenders or their gender. 


\footnotetext{
${ }^{9}$ Here we have also included as "party primaries" those selection events where, because there was a single candidate, the actual members' vote was eventually cancelled.

${ }^{10} \mathrm{We}$ find this pattern both at the national and regional levels (see Table 3 in Appendix A).

${ }^{11}$ The average number of female contenders increases from 1.1 under the exclusive selection methods to 1.2 under primaries. In the case of men, it increases from 1.8 to 2.5 .

${ }^{12}$ We have rerun model 3 with all mayors -no matter the size of their municipality- considered as "political insiders". Results did not change.

${ }^{13}$ In case the type of leadership sought (party leadership or top candidacy) had some effect on women's chances of winning a contest, we have rerun model 3 excluding those candidates ( 27 cases) who run in a contest for party's top candidacy. Results are basically the same.
} 